\title{
PRIMENA RADIOAKTIVNOG JODA U DIFERENCIRANOM TIROIDNOM KARCINOMU DEČIJEG UZRASTA
}

Juvenilni diferencirani tiroidni karcinom (DTK) [papilarni - PTK, i folikularni - FTK] je redak malignitet; čini 0.5 - 3\% svih dečijih karcinoma. Incidenca javljanja juvenilnog tiroidnog karcinoma iznosi $1 \%$ u dece pre puberteta i $7 \%$ u periodu adolescencije (15-19g). Juvenilni DTK često se javlja u agresivnoj kliničkoj formi. U oko $60 \%$ do $80 \%$ bolesnika na samom startu imaju metastaze u vratne limfne čvorove a one su često udružene sa udaljenim metastazama, ali bez povećanja ukupne smrtnosti. Tretman DTK je isti kao i u odraslih a podrazumeva hirurški tretman uz radiojodnu ablaciju sa radioaktivnim jodom ${ }^{131}$ I. Radiojodna ablacija dece razlikuje se po veličini aktivnosti od radiojodne ablacije odraslih. Prema uputstvima Evropske asocijacije nuklearne medicine, proračunavanje aktivnosti može se vršiti na osnovu telesne težine pacijenata $(\mathrm{MBq} / \mathrm{Kg}$ telesne težine), površine tela pacijenta ili na osnovu starosti bolesnika (deca do 5 godina starosti dobijaju 1/3 doze za odrasle; deca 6 do 10 godina dobijaju polovinu doze za odrasle; deca od 11-15 godina dobijaju 5/6 doze za odrasle; a adolescenti dobijaju doze kao i odrasli). Nemačko udruženje nuklearne medicine proračunava veličinu date aktivnosti na osnovu 24-satne radiojodne fiksacije i to: ako je fiksacija manja od $5 \%$ daje se $50 \mathrm{MBq} / \mathrm{Kg}$; pri fiksaciji $5-10 \%$ daje se $25 \mathrm{MBq} /$ $\mathrm{kg}$ telesne težine; a pri fiksaciji $10-20 \%$ daje se $15 \mathrm{MBq} / \mathrm{kg}$ telesne težine. Rezultati studije rađene u našoj ustanovi, koja obuhvata period od početka januara 1977. do kraja decembra 2012. godine pokazuju da su 1502 bolesnika sa DTK lečena sa ${ }^{131}$ I. Od njih, bilo je 53 bolesnika sa juvenilnim DTK a detaljno je analiziran 51 bolesnik jer su dva bolesnika ispala iz praćenja. U bolesnika pre puberteta, aktivnost radiojoda je određena na bazi težine (50-100 MBq/kg), a u bolesnika nakon puberteta davana je metoda fiksne aktivnosti: $3.7 \mathrm{GBq}$ za ablaciju ukoliko nije bilo regionalnih i udaljenih metastaza (NOM0) i 5.55-7.4 GBq u bolesnika sa regionalnim i/ili udaljenim metastazama (N1M0/N1M1). Tokom praćenja, u 21.6\% bolesnika nađen je recidiv. Preživljavanje je iznosilo $98 \%$; kompletna remisija bolesti nađena je u $90.2 \%$ bolesnika; parcijalna remisija u 3.92\%; stabilna bolest u 1.96\%; smrtnost od osnovne bolesti u $1.96 \%$, i smrt usled drugog uzroka u $1.96 \%$ bolesnika. Uprkos visokom procentu recidiva, juvenilni DTK ima dobar ishod i prognozu. Mlađi pacijenti, manje radikal-

1 Zavod za nuklearnu medicinu, Institut za onkologiju Vojvodine, Sremska Kamenica. 
na hirurgija bez ${ }^{131} \mathrm{I}$, i multifokalnost tumora su jaki prognostički faktori za nastanak recidiva. U cilju smanjenja relapsa i poboljšanja monitoringa totalna ili skoro totalna tiroidektomija praćena radiojodnom ablacijom preporučuje se kao najpogodniji inicijalni tretman. Primena radioaktivnog joda je sigurna metoda bez adverznih efekata na fertilitet žena i trudnoću ili pojavu sekundarnog maligniteta. 